\title{
An Empirical Investigation of the Relationship between Organizational Culture and Customer Orientation: The Mediating Effect of Knowledge Management (An Empirical Study in the Household Appliance Industry in Iran)
}

\author{
Hassan Ghorbani \\ Department of Management and Accounting, Islamic Azad University \\ Mobarakeh Branch, Isfahan, Iran \\ Tel: 98-311-666-2096 E-mail: ghorbani2007ha@yahoo.com
}

Seyedeh Masoomeh Abdollahi Demneh (Corresponding author)

Department of Management, University of Isfahan, Hezarjerib Street, Isfahan, Iran

E-mail: Masumeh_abdolahi@yahoo.com

Arezoo Khorsandnejad

Department of Management, University of Isfahan, Hezarjerib Street, Isfahan, Iran

E-mail: A_Khorsandnezhad@yahoo.com

Received: December 27, $2011 \quad$ Accepted: February 1, $2012 \quad$ Published: June 1, 2012

doi:10.5539/ijms.v4n3p58 URL: http://dx.doi.org/10.5539/ijms.v4n3p58

\begin{abstract}
Customer orientation has emerged as a significant antecedent of organizational performance and it is presumed to contribute relating organization's members to customers as one of the main external forces of the organization's environment and to long-term success. Internal characteristics of the organization such as culture are likely to be influential on this concept. This study aims to investigate the linkage between dimensions of organizational culture and customer orientation, regarding the mediating role that knowledge management can play to enhance this relation. The statistical population consists of managers and staff of Iran's household appliance industry. Random sampling method has been applied to select the appropriate sample. The examinations were done through 192 available questionnaires. In order to test the conceptual model, structural equations' model (SEM) has been used. Amount of goodness indexes (AGFI=0.89, GFI=0.90) shows suitability of the model.

Results based on SEM outputs demonstrate acceptance and confirmation of all studied factors. These findings indicate that organizational culture affects knowledge management in a positive way and knowledge management in turn, can influence customer orientation positively.
\end{abstract}

Keywords: Customer orientation, Knowledge management, Organizational culture, Entrepreneurial proclivity, Quality context

\section{Introduction}

The internal characteristics of the organization make up critical sources for success (Zheng et al, 2010). Increasing attention has been paid to identifying what organizational contextual factors are vital to organizational success in the competitive environment and how they work as competitive advantages of the organization. Market orientation, also has been introduced as an important organizational antecedent of business success (Han, Kim, and Srivastava, 1998). Market orientation pertains to an organizational culture that emphasizes aspects such as customer orientation, competitor orientation, interfunctional coordination, and responsiveness as keys to organizational success (Raju et al, 2011). Customer orientation can play a prominent role in this area. Acquiring 
knowledge about customers and competitors and sharing this information between functional areas within a firm are key dimensions of a market orientation approach (Darroch and McNaughton, 2003). Customer orientation has been discussed as a key profitability factor to a business, and it is also a business's goal in the practice of marketing management (Chi et al, 2007). However, what is questionable for managers is how to create the environment in which employees can achieve this sight. Researchers propose the idea of Knowledge Worker to outline the future environment of workplace and career of future worker (Darroch and McNaughton, 2003).

Knowledge is increasingly recognized within marketing management as a critical resource that can be managed to enhance the competitive position and financial performance of a firm (Darroch and McNaughton, 2003). Moreover, knowledge management is a cycle process. In order to transfer knowledge to workers effectively, an organization has to build trust and consensus culture to fit and support knowledge transfer. Only by knowledge management system, an organization can learn continuously and make best use of knowledge (Chi et al, 2007). It highlights the linkage between organizational context and knowledge management. Knowledge management plays a potentially mediating role in connecting organizational context with customer orientation. Successful knowledge management is believed to have the potential of enhancing an organization's competitive advantage, customer focus, employee relations and development, innovation, and lower costs (Zheng et al, 2010). This study attempts to examine the possible mediating effect of knowledge management on the relationship between organizational culture and customer orientation.

\section{Literature Review}

\subsection{Customer Orientation}

Researchers suggest that customer orientation can be regarded as the application of marketing concepts in salespersons service and customer interaction (Chi et al, 2007). Customer-orientation behavior focuses on the extent to which salespeople practice the marketing concept by helping their customers make purchase decisions that will satisfy their Needs (MohdNoor and Muhamad, 2005). It usually reflects a salesperson's confidence to satisfy customer need and his or her willingness to interact and service them (Brown, et al, 2002). Customer orientation implies a salesperson's tendency and motivation to pamper the customer, read customer's needs, develop interpersonal relationship, and to deliver the required service (Donavan et al., 2004). It is based on paying attention to a long term customer satisfaction, and avoiding sacrificing customer benefits in order to increase a short term sales (Franke and Park, 2006). The performance of a sales representative's behavior on customer contact will directly impact on a customer purchase and repurchase action (Chi et al, 2007). Customer will perceive service quality through salespersons' behavioral delivery (Darroch and McNaughton, 2003). In addition, a high customer orientation in a salesperson's service can lead to enhance customer satisfaction, and it will also help an organization to develop a long term relationship with a customer (Chi et al, 2007). In order to access these goals the units of analysis at organizations emphasis on collecting and gathering market information to employees, to increase interdepartmental connectedness within the firm, and creating a customer-oriented organizational culture in which customer satisfaction is essentially at the core of every decision for every employee (Jones, Busch and Dacin, 2003).

\subsection{Knowledge Management}

Nowadays managers are aware about the importance of intellectual capital as one of the intangible assets of the organizations. They know that in order to succeed, a business must store intellectual capital and practice knowledge management thoroughly (Chi et al, 2007). Researchers indicate that intellectual capital is the sum of knowledge and an employee's ability to render a competitive advantage for an organization. They believe that any knowledge that can create fortune and information and become intellectual property and experience is called intellectual capital (Stewart, 1997). Knowledge management is this intellectual capital which can be considered as a manageable asset. It can help an organization to innovate and adjust in the face of change and promote a corporate value (Chi et al, 2007). Scholars have identified four dimensions for the mechanism of knowledge management. They state that knowledge management encompasses knowledge innovation, knowledge accumulation, knowledge diffusion, and knowledge transfer as its dimensions (Tan et al, 1999).

As mentioned in previous parts, successful knowledge management is believed to have the potential of enhancing an organization's competitive advantage, customer focus, employee relations and development, innovation, and lower costs. However, it has been considered that the knowledge management practices in the organizations depend on some prerequisites (Tahir. et al, 2010). In other words, knowledge management can be influenced by organizational contextual factors. Studies have shown that knowledge management is context-specific, because context determines who participate and how they participate in the knowledge management process (Nonaka et al., 2000). On the other hand, it is a pre-condition to the organization's 
competitive advantages such as customer orientation. In fact, knowledge management serves as an antecedent to customer orientation, as it is a medium between organizational factors and customer orientation. The literature on the possible mediating role of knowledge management covers some ground of the contextual antecedents of knowledge management (Lee and Choi, 2003). Knowledge resources are an outcome of organizational culture and structure, because knowledge is created, made sense of, and utilized in accordance with a set of cultural values and norms, embedded in structural relationships, and reflected in cultural norms (Zheng et al, 2010).

\subsection{Organizational Culture and Knowledge Management}

A number of authors have stressed that competitive advantage through knowledge management is realized through identifying the valuable tacit knowledge possessed by organizational members and making that knowledge explicit (Balthazard and Cooke, 2004). Organizational culture refers to shared assumptions, values, and norms (Schein, 1985). Deshpande and Webster (1989) believe that organizational culture as the set of shared values helps organization's members understand organizational functioning and therefore guide their thinking and behavior. Organizational culture is a source of sustained competitive advantage and empirical research shows that it is a key factor to organizational effectiveness (Zheng et al, 2010). Thus, based on previous studies it can be considered that organizational culture can influence market orientation as one of the important factors of organizational effectiveness and customer orientation, in turn, can be affected by this contextual factor. Notably, researchers claim that Organizational culture does not directly lend its influence on customer orientation; rather, it exerts its influence through shaping the behavior of organizational members (Zheng et al, 2010). Regarding the mediating role of knowledge management (Rastogi, 2000), it can be the linking factor. Existing literature implies a positive relationship between organizational culture and knowledge management (Zheng et al, 2010). In fact, one of the important prerequisites for effective knowledge management is organizational culture (Tahir. et al, 2010). Researchers have identified various dimensions for organizational culture regarding different aspects of organizational success. Our work attempts to link Organizational learning, market focus, entrepreneurial proclivity and quality context as four cultural variables (Raju et al, 2011) to knowledge management.

Organizational learning is characterized as an evolutionary approach to strategy where organizations don't just depend on existing resources, but constantly evolve through learning, discovery, and adaptation. A firm's capacity to gather and interpret knowledge from the market, or "market-sensing capability", is seen to derive from knowledge management (Raju et al, 2011). Market focus is considered to be a function of the emphasis top management places on customer orientation and of the degree to which managers are rewarded on the basis of market-based factors (Jaworski and Kohli, 1993). Hurley and Hult (1998) further claim that a market focus helps stimulate new ideas and improve responsiveness to markets. Knowledge management practices can support this flow. Entrepreneurial proclivity refers to an entrepreneurial predisposition characterized by the dimensions of innovativeness, risk taking, and proactiveness (Raju et al, 2011). Researcher's finding of the positive relationship between entrepreneurship which in turn incorporates adaptability and innovation highlights the role of knowledge management in facilitating this process (Brockman and Morgan, 2003). In the management literature, quality context refers to an organizational culture conducive to producing a quality product or service. Top management knowledge of quality is a major dimension of quality context, so Knowledge management practices can be influential to cultivate this approach among management and organizational members (Raju et al, 2011). Therefore, according to what is mentioned previously developed hypotheses are stated as:

H1: Organizational learning is positively related to knowledge management.

H2: Market focus is positively related to knowledge management.

H3: Entrepreneurial proclivity is positively related to knowledge management.

H4: Quality context is positively related to knowledge management.

\subsection{Customer Orientation and Knowledge Management}

Despite the importance of customer's attitude toward the organization, it is not enough only to satisfy a customer's needs, rather, salespersons need to use technological equipments to understand customer experiences (Manning and Thorne, 2002). Salespersons have to learn how to cope with competition and keep a good performance in order to survive (Chi et al, 2007). In other words, knowledge must be effectively analyzed, stored and used through a suitable knowledge management, and it will help salespersons to intensify their ability to service quality and provide a customerized service. In fact, a knowledge management orientation is a broader concept, encompassing both market based information and information about non-market factors such as technology and internal financial information (Darroch and McNaughton, 2003). Furthermore, customer's needs 
will differ according to products and customers themselves, and the more a salesperson interacts with a customer, the more knowledge can be obtained from customers. After knowledge is stored, shared and used, a salesperson can be more successful to provide and satisfy customer needs (Chi et al, 2007). These findings illustrate the linkage between knowledge management in an organization and the degree of success in creating customer orientation approach among organization's members. Therefore, it can be claimed that there is a meaningful relation between knowledge management and customer orientation, and the developed hypothesis is presented as:

H5: knowledge management is positively related to customer orientation.

\section{Conceptual Framework of Study}

This study attempts to investigate the relation between organizational culture and customer orientation as a marketing factor which can relate the organizational concepts and market, considering knowledge management as the mediating variable. In accordance with literature review and based on developed hypothesis the conceptual framework of the study is hypothesized. Figure 1 illustrates the conceptual model of the research (refer to notes).

\section{Research Methodology}

In order to investigate predicted relations, a self-administered survey was used to collect data on organizational members' perceptions of the three constructs: organizational culture, knowledge management, and customer orientation. The questionnaire includes 38 items in which 35 items were assigned to 6 latent variables (organizational learning, market focus, entrepreneurial proclivity, quality context, knowledge management and customer orientation), and 3 items to demographics variables. All items in the questionnaire are measured by Likert's five-point scale. In this study, measures assessing customer orientation were adopted from Raju et.al (2011) in order to extract the status of customer orientation acceptance among units. Items measuring knowledge management were modified from Gold et al. (2001), assessing respondents' perception of the existence of the four dimensions of knowledge management and the items assessing organizational culture were adapted from Zheng et al, (2010) which capture organizational members' perceptions of the current status of four cultural variables (organizational learning, market focus, entrepreneurial proclivity and quality context) in the organizations. The reliability of the questionnaire which is estimated by The Cronbach's Alpha Coefficients equal 0.802 for the items assessing customer orientation, 0.754 for the items of knowledge management and 0.824 for the items of organizational culture which are in an acceptable range.

\subsection{Sample Selection and Date Collection}

The research population contains of managers and staffs of Iran's household appliance industry. Random sampling method was used to have a sample of 200 respondents. A total of 192 usable questionnaires out of 200 were returned, which demonstrates a response rate of 96 percent. The final analysis was performed based on 192 questionnaires. Table 1 addresses the demographic characteristics of the respondents (refer to notes).

\section{Results}

Confirmatory Factor Analyses were performed to check the validity of the constructs and to determine the related items. CFA on organizational culture including 19 items (4 items for organizational learning, 5 items for market focus, 6 items for entrepreneurial proclivity and also 4 items for quality context), knowledge management with 9 and on customer orientation with 7 items confirmed the suitability of the measures to be used for further analysis.

The research's hypotheses were tested by Structural Equation Analyses (SEM) using LISREL software. The structural equation modeling technique enables the simultaneous estimation of multiple regression equations in a single framework. All direct and indirect relationships in the model are estimated simultaneously, and therefore the method allows all the interrelationships among the variables to be assessed in the same decision context. Researchers have recommended that a sample size 100 to 200 is appropriate for Structure Equation Model (SEM) analysis (Bollen, 1989). The sample size in this study was 192, so SEM analysis could be applied. Covariance matrices were analyzed in all cases using LISREL software. The correlation matrix of data is shown in table 2. The result indicates chi-square is 501.76 calculated by LISREL software. $\chi^{2} / \mathrm{df}=2.01$, the lower amount of $\chi^{2}$ / df demonstrates the suitability of the proposed model. Other results based on LISREL's output are P-value $=0.09$, RMSEA $=0.005$. Such results prove the proposed model. Figure 2 shows the principal model of research and figure 3illustrates the results of the hypothesis testing (refer to notes). Circumstantial evidence $t$ is used to find out if proposed relationships are significant or not. This circumstantial evidence refers to the proportion of each parameter's coefficient to the standard deviation error of that parameter which will be significant when it is 
higher than $2(\mathrm{t} \geq 2)$ in $\mathrm{t}$-test and higher than $1.96(\mathrm{z} \geq 1.96)$ in $\mathrm{z}$-test. Figures demonstrate that the model indicates no insignificant paths. All other goodness of fit indices is within the acceptable ranges (GFI $=0.90$, $\mathrm{AGFI}=0.89, \mathrm{CFI}=0.94, \mathrm{RMSEA}=0.005, \mathrm{NFI}=0.90$ ). All of the fit indices indicate that the proposed model exhibits a reasonably good fit to the data. According to what is mentioned, following results can be extracted:

As expected in the first hypothesis, organizational learning was found to influence knowledge management positively $\left(\mathrm{H} 1: \gamma_{1}=0.35, \mathrm{p}<0.05\right)$ and as predicted in second hypothesis market focus also has a positive influence on knowledge management $\left(\mathrm{H} 2: \gamma_{2}=0.20, \mathrm{p}<0.05\right)$. The third hypothesis predicted that entrepreneurial proclivity has a positive impact on knowledge management, statistic results confirmed this prediction as well (H3: $\left.\gamma_{3}=0.41, \mathrm{p}<0.05\right)$. As proposed by hypothesis 4 quality context was found to influence knowledge management positively $\left(\mathrm{H} 4: \gamma_{4}=0.21, \mathrm{p}<0.05\right)$. Therefore, organizational culture could affect knowledge management positively. Finally, in a same way, the significant and positive relation between knowledge management and customer orientation was supported (H5: $\left.\gamma_{5}=0.65, \mathrm{p}<0.05\right)$. Generally all of research hypotheses were confirmed statistically. The results are shown in table 2 (refer to notes).

\section{Conclusion}

The main purpose of this study was to investigate how organizational contextual factors and member's perception of these concepts in the organization can influence the ability of the organization to achieve a better insight about the importance of customer's attitude toward the organization's practices and the benefits derived by using this approach for both management and employees and also how important role can knowledge management play to enhance these perceptions and relations. The findings indicate that organizational culture can influence knowledge management, and knowledge management, in turn can affect customer orientation approach in the organizations. Based on these findings, the more organizational learning, market focus, entrepreneurial proclivity and quality context spread through organizational members the better knowledge could be managed in order to increase the organization's potential to greatly conquest the competitive environment surrounding it. Willingness to discover, adaption and learn the latest changes in the environment could facilitate knowledge development and management trends in the organization. In addition, a market focus helps stimulate new ideas and improve responsiveness to markets which acts as a facilitator for enhancing knowledge management. It is also confirmed based on the study's findings that the degree of tendency for innovativeness and proactiveness can lead organizational members to enhance the organization's status and management can reinforce this process by promote knowledge among employees, and according to the results creating knowledge of quality affects the insight of producing products and services with high levels of quality, therefore, Knowledge management practices can be influential to cultivate this approach among management and organizational members. Besides providing empirical evidence to the connection between knowledge management and customer orientation, this study suggests that knowledge management could be an intervening mechanism between organizational culture and customer orientation. According to these findings, knowledge management is not only the way to get the superior status in the market and among competitors, but also a central mechanism that leverages organizational cultural influence on customer orientation. As the results confirmed the impact of knowledge management on customer orientation, it is suggested that in customer orientation respect, salespersons in the service industries need not only to provide the best service to customers but also to pay more attention to knowledge management to increase their competitiveness. Therefore, if a salesperson is not customer oriented, his or her performance must be affected. Furthermore, it is not enough only to satisfy a customer needs, it is also important for salespersons to develop customer needs by using knowledge management in order to understand customer experiences. It can analyze, store and use information effectively to enhance employee's ability to provide a good quality and customerized service to customers. What is essential to facilitate this trend in all the units and among members is the beliefs and values accepted and shared by them which highlights the importance of applying cultural concepts to strengthen attitudes inside the organization toward the significance of interacting with customers. Since knowledge management is the device used by organizations to create the value of intellectual assets it can increase employees' productivity and this productivity, in turn, can lead to organizational efficiency and productivity.

\section{References}

Adli, Fariba. (2003). Knowledge Management a Movement Toward to Beyond Knowledge. Tehran, Farashenakhtie Andisheh Publication.

Andrews, M. C., \& Kacmar, K. M. (2001). Discriminating among organizational politics, justice, and support. Journal of Organizational Behavior, 22, 347-366. http://dx.doi.org/10.1002/job.92 
Balthazard, P. A., \& Cooke, R. A. (2004). Organizational culture and knowledge management success: Assessing the behavior-performance Continuum. Proceedings of the 37th Hawaii International Conference on System Sciences.

Bollen, Kenneth A. (1989). Social sciences; Latent variables; Statistical methods. New York: Willey, 514.

Brockman, B. K ., \& Morgan, R. M. (2003). The role of existing knowledge in new product innovativeness and performance. Decision Science, 34(2), 385-419. http://dx.doi.org/10.1111/1540-5915.02326

Chen, C., \& Huang, J. (2007). How organizational climate and structure affect knowledge management-The social interaction perspective. International Journal of Information Management, 27, 104-118. http://dx.doi.org/10.1016/j.ijinfomgt.2006.11.001

Chi, H. K, Yeh, H. R., \& Chen, Y. L. (2007). The Mediating Effect of Knowledge Management on Customer Orientation and Job Performance of Salespeople.

Darroch, J., \& McNaughton, R. (2003). Beyond market orientation Knowledge management and the innovativeness of New Zealand firms. European Journal of Marketing, 3/4 (37), 572-593. http://dx.doi.org/10.1108/03090560310459096

Donavan, D. T., Brown, T. J., \& Mowen, J. C. (2004). Internal benefits of service-worker customer orientation: job satisfaction, commitment, and organizational citizenship behaviors. Journal of marketing, 68(1), 128-146. http://dx.doi.org/10.1509/jmkg.68.1.128.24034

Franke, G. R., \& Park, J. E. (2006). Salesperson adaptive selling behavior and customer orientation: A meta-analysis. Journal of Marketing Research, 43, 693-702. http://dx.doi.org/10.1509/jmkr.43.4.693

Ghorbani, M., Tavassoli, J., \& Nikookar, M. (2011). Relationship between organizational structure dimensions and knowledge management (KM) in educational organization. World Applied Sciences Journal, 12(11), 2032-2040.

Gold, A. H., Malhotra, A., \& Segars, A. H. (2001). Knowledge management: an organizational capabilitiesperspective. Journal of Management and Information System, 18(1), 185-214.

Han, J. K., Kim, N., \& Srivastava, R. K. (1998). Market orientation and organizational performance: is innovation a missing link? Journal of marketing, 62, 30-45. http://dx.doi.org/10.2307/1252285

Hurley, R. F., \& Hult, G. T. M. (1998). Innovation, market orientation, and organizational learning: an integration and empirical examination. Journal of Marketing, 62, 42-54. http://dx.doi.org/10.2307/1251742

Jaworski, B. J., \& Kohli, A. K. (1993). Market orientation: antecedents and consequences. Journal of Marketing, 57, 53-70. http://dx.doi.org/10.2307/1251854

Jones, E., Busch, P., \& Dacin, P. (2003). Firm market orientation and salesperson customer orientation: interpersonal and intrapersonal influences on customer service and retention in business-to-business buyer-seller relationships. Journal of Business Research, 56, 323-340. http://dx.doi.org/10.1016/S0148-2963(02)00444-7

Lee, H., \& Choi, B. (2003). Knowledge management enablers, process, and organizational performance: an integrative view and empirical examination. Journal of Management Information System, 20(1), 179-228.

Manning, B., \& Thorne, C. (2002). Demand driven: 6 steps to building an ecosystem of demand for your business. McGraw-Hill Companies.

Mohd, Noor, N. A., \& Muhamad, A. (2005). Individual Factors that Predict Customer-Orientation Behavior of Malaysian Life Insurance Agents. Journal Pengurusan, 24, 125-149.

Nonaka, I., Toyama, R., \& Konno, N. (2000). SECI, Ba, and leadership: a unified model of dynamic knowledge creation. Long Rang Plan, 33, 5-34. http://dx.doi.org/10.1016/S0024-6301(99)00115-6

Raju, P. S., Lonial, S. C., \& Crum, M. D. (2011). Market orientation in the context of SMEs: A conceptual framework. Journal of Business Research, 64, 1320-1326. http://dx.doi.org/10.1016/j.jbusres.2010.12.002

Rastogi, P. N. (2000). Knowledge management and intellectual capital - the new virtuous reality of competitiveness. Human System Management, 19(1), 39-49.

Schein, E. H. (1985). Organizational culture and leadership: a dynamic view. San Francisco, CA: Jossey-Bass,

Sivadas, E., \& Dwyer, F. R. (2000). An examination of organizational factors influencing new product success in internal and alliance based processes. Journal of Marketing, 64(1), 31-50. http://dx.doi.org/10.1509/jmkg.64.1.31.17985 
Stewart, T. A. (1997). Intellectual capital: The new wealth of organizations. New York: Doubleday Currency.

Tahir, S., Basit, T., Haque, M. A., Mushtaq, A. H., \& Anwar, Ch. (2010). Knowledge management practices: Role of organizational culture. ASBBS Annual Conference: Las Vegas, 1(17), 1027-1036.

Tan, D. C., Liu, T. Y., \& Tsai, M. C. (1999). Literature reviews and classifications of knowledge management. Proceedings of Chinese society for management of technology. Taiwan: National Sun Yat-sen University.

Tsai, W. (2002). Social structure of "coopetition" within a multiunit organization: Coordination, competition, and intra-organizational knowledge sharing. Organization Science, 13(2), $179-190$. http://dx.doi.org/10.1287/orsc.13.2.179.536

Zheng, W., Yang, B., \& McLean, G. N. (2010). Linking organizational culture, structure, strategy, and organizational effectiveness: Mediating role of knowledge management. Journal of Business Research, 63, 763-771. http://dx.doi.org/10.1016/j.jbusres.2009.06.005

Table 1. Sample demographic characteristics

\begin{tabular}{|c|c|c|c|}
\hline Variable & Type & Frequency & Percent \\
\hline Gender & Female & 115 & 59.9 \\
\hline & Male & 73 & 63.5 \\
\hline Age & $21-30$ & 122 & 16.1 \\
\hline & $31-40$ & 31 & 12 \\
\hline Educational & $41-50$ & 23 & 7.3 \\
\hline status & More than 50 & 14 & 23.4 \\
\hline & High school & 45 & 36.5 \\
\hline & Diploma & 70 & 31.2 \\
\hline & Bachelors & 60 & \\
\hline & Masters and Ph.D & & \\
\hline
\end{tabular}

Table 2. Analysis of results

\begin{tabular}{|c|c|c|c|c|}
\hline \multicolumn{2}{|c|}{ Path } & Hypotheses & Coefficient & T-value \\
\hline $\begin{array}{c}\text { Organizational } \\
\text { learning }\end{array}$ & $\begin{array}{c}\text { Knowledge } \\
\text { management }\end{array}$ & $\mathrm{H} 1$ & $0.35^{*}$ & 16.44 \\
\hline Market focus & $\begin{array}{c}\text { Knowledge } \\
\text { management }\end{array}$ & $\mathrm{H} 2$ & $0.20^{*}$ & 20.09 \\
\hline $\begin{array}{c}\text { Entrepreneurial } \\
\text { proclivity }\end{array}$ & $\begin{array}{c}\text { Knowledge } \\
\text { management }\end{array}$ & $\mathrm{H} 3$ & $0.41^{*}$ & 20.17 \\
\hline $\begin{array}{c}\text { Quality context } \\
\text { management }\end{array}$ & $\begin{array}{c}\text { Customer } \\
\text { orientation }\end{array}$ & $\mathrm{H} 5$ & $0.65^{*}$ & 14.07 \\
\hline $\begin{array}{c}\text { Knowledge } \\
\text { management }\end{array}$ & \multicolumn{2}{|c|}{} & & \\
\hline
\end{tabular}


Table 3. Fit indices for the path model

\begin{tabular}{|l|l|}
\hline$\chi^{2} / \mathrm{df}$ & 2.01 \\
\hline GFI & 0.90 \\
\hline AGFI & 0.89 \\
\hline RMSEA & 0.005 \\
\hline NFI & 0.90 \\
\hline CFI & 0.62 \\
\hline
\end{tabular}

Notes: CFI: Comparative Fit Index; GFI: Goodness of Fit Index; AGFI: Adjusted Goodness of Fit Index; SRMR: Standardized Root Mean Square Residual; RMSEA: Root Mean Square Error of Approximation; ${ }^{*} \mathrm{p}<0.05$.

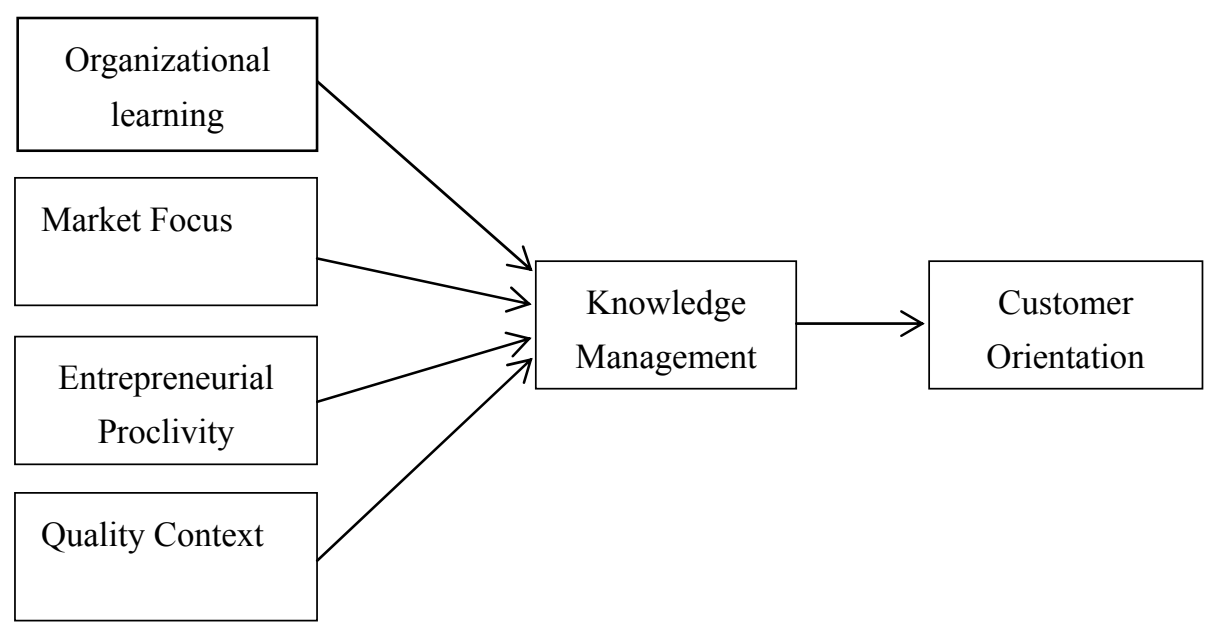

Figure 1. Conceptual frame work of study 


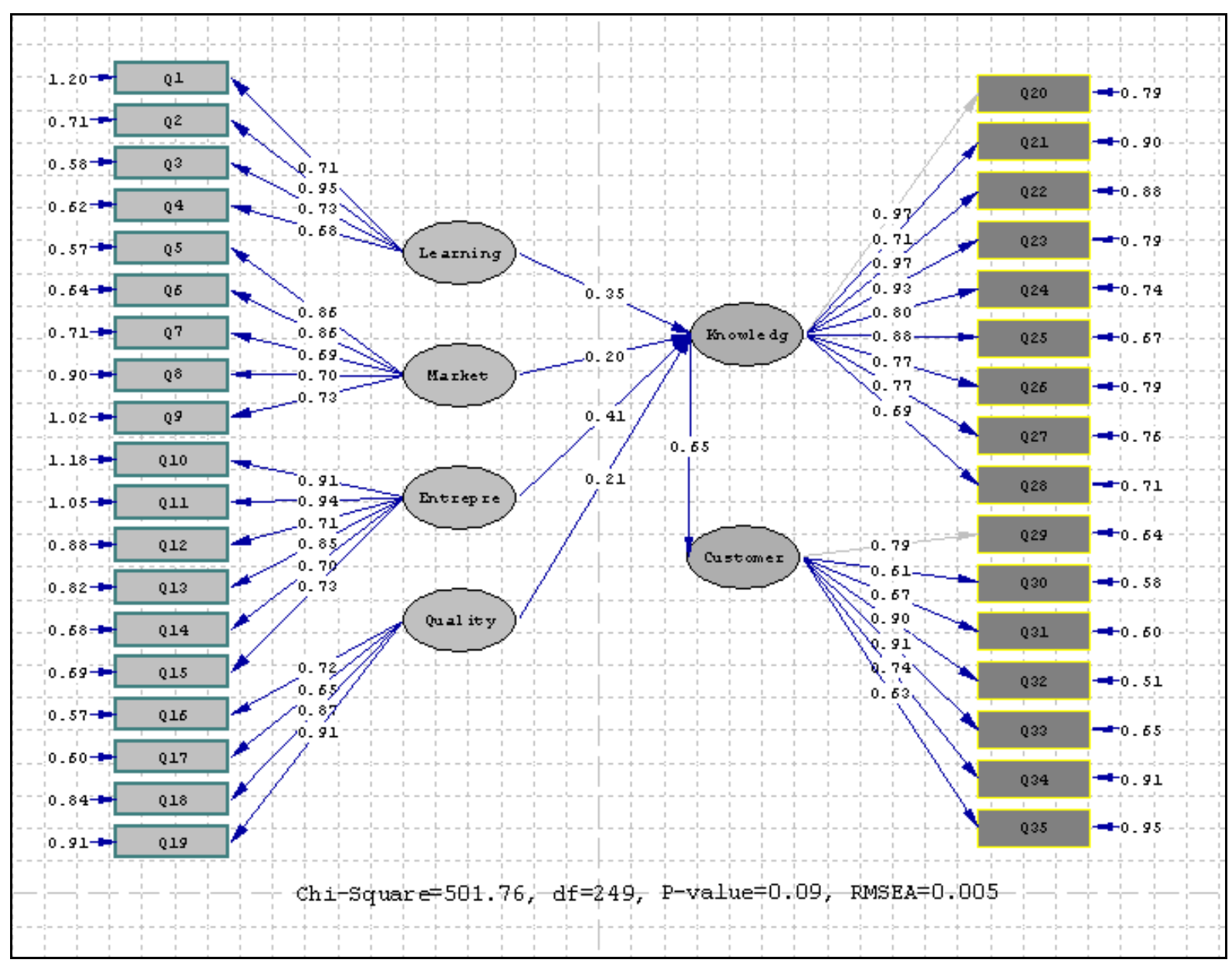

Figure 2. Principal model of research 


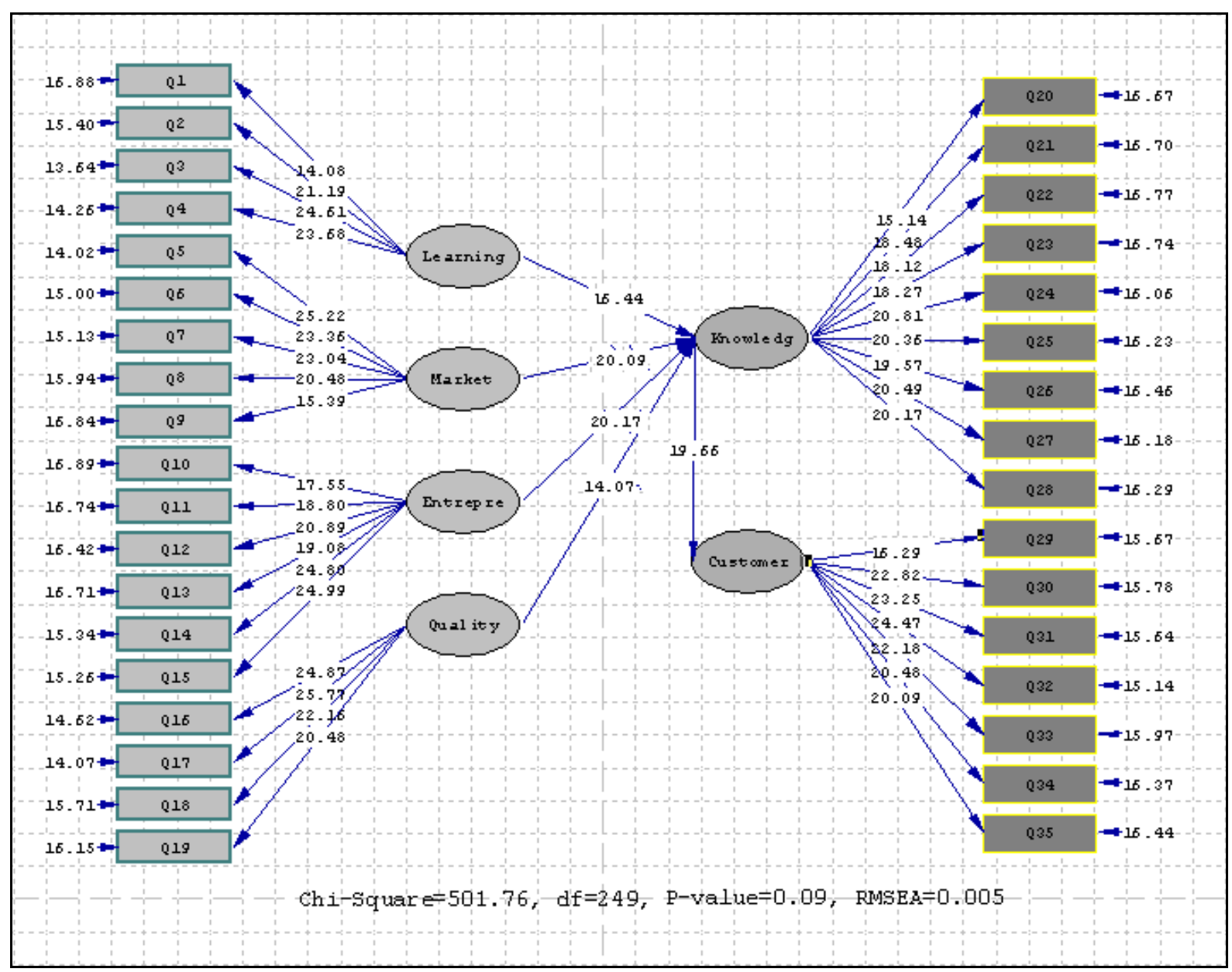

Figure 3. Model of adjusted index of T 